\title{
Types of IT Architects: A Content Analysis on Tasks and Skills
}

\author{
Christof Gellweiler ${ }^{1}$ \\ ${ }^{1}$ WHU - Otto Beisheim School of Management, Vallendar, Germany, christof.gellweiler@whu.edu \\ Received 20 February 2019; received in revised form 1 June 2019; accepted 2 June 2019
}

\begin{abstract}
Information technology architecture is an essential element of an enterprise's strategy and impacts competitive advantage. The management of information technology architectures is unexplored in theory and confused in practice. In particular, the roles of information technology architects are interpreted in various ways. The purpose of this study is to examine the roles of information technology architects by investigating the required activities and skills demanded in the human resources market. In-depth content analysis was applied on job advertisements Categories were inductively developed by allocating meaning units until saturation: 2438 meaning units were assigned to 37 task categories and 49 skill categories. As a result, three types of architects with distinctive profiles were identified. In addition to technological expertise, all architects must provide outstanding social and methodological skills. Knowledge of particular frameworks is rarely required. Skills and architect types from The Open Group Architecture Framework were disproved in parts. Attributes specific to e-commerce architects and digital architects were elaborated. The found task and skill categories may be used as catalogs for recruiting purposes in practice.
\end{abstract}

Keywords: IT architect, Enterprise architect, E-Commerce architect, Digital architect, TOGAF, ITbusiness alignment 


\section{Introduction}

Enterprise architecture (EA) is a developing management discipline [32] that is receiving growing attention in industry and science. EA comprises and organizes all pertinent elements and processes of an enterprise [36] p. 526. The scope of EA includes strategy, decisions, planning, human resources, assets, tasks, design processes, results, etc. [8] p. 644. EA management guides the evolution of enterprises and strives to enhance IT-business alignment [10] p. 152. Information technology (IT) architecture is an element of the strategic alignment process along with IT strategy, business strategy, and the organization [4]. IT is an instrument for achieving and sustaining competitive advantage [55] p. 85 used to empower the business strategy [52] p. 15. The IT architecture is a source of differentiation among competitors and can translate into a business advantage [24] p. 37. Thus, managing enterprise and IT architectures is a momentous capability for competitive advantage and has notable strategic importance.

EA describes IT, processes, individuals, procedures, projects, and their relationships [41] p. 445. It attempts to integrate, align, and administer various components of an enterprise to exploit synergies in accomplishing enterprise goals [69] p. 2. Numerous frameworks, for example, [19], [81], (Site 2), (Site 3), try to translate the EA complexity to make it manageable for practical use. However, those EA frameworks are too general and abstract and consequently, not applicable by practitioners [12] p. 5. Furthermore, multiple comprehensive frameworks exist for other IT-related management disciplines, such as business analysis [41], project management [66], and system engineering [8]. These frameworks describe processes and elements of IT management from different views but are isolated from other frameworks.

Diverse studies on EA management have been conducted. Most research subjects are strategies, processes, principles, and drivers for putting EA into effect [45] p. 526. However, the role of the enterprise architect is unclear in theory and practice [82]. The Open Group Architecture Framework (TOGAF) framework [81] p. 472 notes the very poor definition of IT architects in the industry. Researcher [59] conducted a case study on EA in the Norwegian health sector and found that the EA role was not understood at all. That circumstance resulted in confusion regarding the enterprise architect's involvement in projects. Interestingly, even the enterprise architects themselves were not clear about their roles. The role of IT architects in e-commerce projects is particularly blurred, since e-commerce architecture subject is being researched across diverse IT areas [3] p. 28.

Little academic research on the IT architects' role has been carried out [32]. In [26], the authors analyzed contents of job advertisements to understand the trends in demands for IT professionals between 1988 and 2003. This study did not present any architect jobs, although ideas on IT architecture were published previously [91]. In [31], the author complained that too little attention had been given the architect role and suggested further studies on it, specifically the system architect.

The purpose of this paper is to explore the roles of the IT architect by investigating the market demands for human resources. IT architects' activities and skills are examined by analyzing job advertisements. Types of IT architects are identified; characteristics of e-commerce projects relevant to IT architects are worked out. This study answers the following research questions: What are the tasks of IT architects? What skills are required for IT architects? How can IT architects be categorized? What are special features for IT architects in e-commerce projects?

To address the research questions, content analysis was carried out by identifying and allocating meaning units. Categories for tasks and skills were created based on the data and iteratively readjusted. This research provides catalogs for architect tasks and skills and suggests a typology of IT architects founded on task focus and derived from the evaluated data. The outcomes are discussed with challenges that IT architects must master in e-commerce projects and in the digital transformation. This paper contributes to theory by defining three main categories of IT architects based on their competences and activities. The findings of this study partly refute the skills and the EA types in the leading architecture framework TOGAF [81]. This research adds substantially to our understanding of the role of the IT architect in various contexts.

The paper is organized as follows. The literature analysis inquiries into the notions of IT/enterprise architecture and presents architect tasks and skills by reflecting dominant IT frameworks and influential academic publications. Then, the chosen methodology is described in detail. The finding section introduces a typology for architects and displays tables of skills and tasks for three types of IT architects. Subsequently, the discussion elaborates on ecommerce/digital architects' characteristics, reflects limitations, and proposes paths for future research.

\section{Literature Review}

The roles of architects in IT environments are considered in different ways. The following subsections present definitions of IT/enterprise architecture and point associated tasks and skills from frameworks, standards, and research papers. 


\subsection{Definitions of IT Architecture}

To understand the role of IT architects, the general idea of IT architecture must be illuminated. Definitions from various institutions and their standards help capture the sense of IT architecture. The different descriptions do not contradict but supplement each other to gain a holistic picture.

The TOGAF framework [81] p. 22 displays architecture as a "structure of components, their interrelationships, and the principles and guidelines governing their design and evolution over time" and refers to the ISO/IEC/IEEE standard [43], an international architecture standard for systems and software. This standard describes system architecture as "fundamental concepts or properties of a system in its environment embodied in its elements, relationships, and in the principles of its design and evolution" [43] p. 2. Examples of systems are software, data, hardware, services, processes, procedures, facilities, materials, and humans [43] p. 3. The framework (Site 2) refers to the same definitions for architecture and adds "overall design of a building, structure, or system that unifies its components or elements into a coherent and functional whole." The Project Management Institute standard [67] p. 65 designates architecture as "a method to describe an organization by mapping its essential characteristics, such as people, locations, processes, applications, data, and technology." Thus, IT architecture may be regarded as a methodology for structuring and governing various connected technical components to coherent systems in accordance to resources and capabilities of an enterprise.

\subsection{Definitions of Enterprise Architecture}

There is no generally accepted glossary for EA; terms and definitions vary over a large range [50] p. 351. Some publications distinguish EA from component or system architectures. The framework [41] p. 441 defines architecture "as the design, structure, and behavior of the current and future states of a structure in terms of its components, and the interaction between those components." An extra specification is given for EA: "A description of the business processes, information technology, people, operations, information, and projects of an enterprise and the relationships between them" [41] p. 445. According to the framework [8] p. 221, architecting involves designing a system structure that can be applied by system engineers to a system, a product, or a service. In contrast, EA describes the structure of an organization.

The framework (Site 3) does not provide its own definition for architecture but characterizes the perspectives via role descriptions. Similar to the frameworks [8], [41], there is a differentiation between EA and components/system architecture. This framework (Site 3) designates the enterprise architect as "designer of a conceptual blueprint that defines the structure and operation of an organization, whereas the enterprise IT architect is responsible for the design of a computing system and the logical and physical interrelationships between its components. The architecture specifies the hardware, software, access methods, and protocols used throughout the system." The enterprise IT architect's responsibility may be related to a physical architecture that is a layout of system components and interfaces to deliver the solution design for a product, service, or enterprise. Physical architecture meets requirements, complies with logical architecture, and can be implemented through technologies (Site 10).

Architecture definitions are dominated by standards and frameworks. Few academic papers deal with those definitions; two are highlighted here. A seminal publication in EA science [91] p. 276 outlined architecture as "logical construct for defining and controlling the interfaces and the integration of all of the components of the system." The author of [74] interviewed 19 IT professionals in software organizations to examine the meaning of architecture in practice. He proposed four architectural metaphors as the outcome. First, blueprint denotes a high-level description of future systems for implementation by engineers and designers. Second, literature means documentation of the technical structure of an as-is solution or a historical collection of the past structure and solutions. Third, architecture provides a language for communication among stakeholders to understand systems and structures. Fourth, architecture is a foundation for decisions regarding strategies, resources, and system implementations.

The framework [42] that claims to connect different frameworks does not elaborate on the notion of architecture but presents good practices for service capabilities. In that context, architecture principles turn up [33] p. 108. These principles are general guidelines for governing IT-related resources in implementation and use, for example, reuse of common components, make-or-buy decisions, simplicity, agility, or open industry standards. Turning from the concept of architecture, those who are responsible for it are discussed.

\subsection{Tasks of IT/Enterprise Architects}

The term IT architect is generic for every architect acting in the IT realm. There are various names for architect roles in the literature that are inconsistent and must be sorted. IT architecture is not a one-size-fits-all subject; several contextual and organizational factors influence the architect role that might be tailored accordingly [7]. Therefore, the descriptions of the work that IT architects undertake are diverse. In the following, I discuss the architect tasks that comprise views from scholars, from a widely used framework, from a standard, and from an IT industry leader. 
In [25], the design of IT infrastructure was regarded as one of three squares that encompasses five of nine IT capabilities and that intersects with the business and IT vision and delivery of IT services. The authors described the role of the architectural planner that performed the following tasks:

- $\quad$ Formulate associated policies that ensure integration and flexibility in IT services

- $\quad$ Shape the IT infrastructure

- Develop the vision for an appropriate technical platform

- Create a coherent blueprint for a technical platform that responds to current and future business needs

- $\quad$ Build relationships with users and business stakeholders

- Take leadership role in robust business/IT relationships

- Support sourcing of IT products and services

- Support implementation of technology

In [79], a qualitative multiple-methods study of the role of the enterprise architect was performed. The data showed that this role appears multi-faceted. The researchers suggested five broad categories [79] p. 385:

- $\quad$ Change agent driving IT strategy toward business objectives

- Communicator among various IT and business roles in decision making and executing plans

- $\quad$ Leader of the team and director for strategic needs

- Manager for team organization and resourcing

- Modeler of links between components

Each category interacts with various other roles. Thus, the enterprise architect is an information-broker between many roles that act as sources or destinations for information.

EA activities from an international German bank were discussed as follows [12] p. 153:

- $\quad$ Create and adjust IT strategy based on the enterprise business strategy

- Collect and analyze needs from business and their importance

- $\quad$ Develop and update architectural guidelines, standards, and principles

- Develop and update architecture artifacts

- $\quad$ Check architecture conformity within projects

The TOGAF framework [81] is the most widely used and best known [36] p. 48. It categorizes architects with different responsibilities for design and documentation [81] p. 474:

- Enterprise architects are at highest level and focus on business functions and leadership

- Segment architects focus on technical solutions for a specific business segment in the value chain

- Solution architects concentrate on products, components, systems, and technologies for a subject matter, for example, security, data management, or networks

This structure is hierarchical for breaking down the holistic business perspectives into detailed solutions designs. The TOGAF framework [81] describes only the EA role and its key characteristics specifically and neglects the activities of segment and solution architects. The following tasks are deduced from the description of the EA role and its characteristics in the framework [81] pp. 472-475: 
- Produce designs, including requirement analysis, technology selection, and configuration

- Operate the infrastructure across distributed systems and various platforms

- Ensure the completeness (fitness for purpose) and integrity of the architecture

- Hand over the design to the project implementers

- Make decisions and work with the project management team

- Lead the team (e.g., segment/solution architects) and communicate to stakeholders

- $\quad$ Guide IT strategically and proactively by recognizing trends and optimizing processes

- $\quad$ Drive and manage the architecture as the agent of change

- $\quad$ Create and improve models for components or solutions and technical references

The ISO/IEC/IEEE international standard [43] does not explicitly describe the architect role but explains architecting during system life cycle and uses of architecture descriptions that contain tasks for an IT architect. The architecture description is a work result from architecting activities [43] p. 8. Architecting is defined as "process of conceiving, defining, expressing, documenting, communicating, certifying proper implementation of, maintaining and improving an architecture throughout a system's life cycle" [43] p. 2.

Cisco Systems offers a global certification program that is highly recognized within the IT industry. Certifications for individuals can be acquired over five qualification levels. At the highest level is the Cisco certified $\operatorname{architect~}\left(\mathrm{CCAr}^{\circledR}\right)$ that has been granted to only ten design engineers throughout the world (Site 5). These architects provide world-class in-depth technology expert knowledge, but their responsibilities are closely linked to business and leadership:

- Understand the business and the impact on architecture, design, and operation

- Decompose a business problem into component parts and determine interaction

- $\quad$ Lead teams consisting of architects in other disciplines (e.g., application and data center) and other roles (e.g., business, financial, facilities, and marketing) to understand the applications and services required to meet the business goals and to specify the properties of the network to support those applications and services

- Define the strategy and priorities for infrastructure, services, and applications

As the role of IT architects is blurry in theory and practice, one cannot expect a uniform view of IT architects' tasks. I presented six examples (three studies, one framework, one standard, and one practice case) that point three facets of the IT/enterprise architect. One facet connects to identifying future business needs and to driving the strategy accordingly. Another facet relates to social tasks such as leading, communicating with stakeholders, and relationshipbuilding. As expected, the technology facet is central (infrastructure, components, products, etc.) and may comprise different activities in linked fields, e.g., product sourcing, project implementation. In the discussion section the tasks in the literature will be compared with the collected data.

\subsection{Skills of IT/Enterprise Architects}

The skills requirements for a professional depend on the type of tasks. If the tasks are unstructured, then the skills are unclear. Thus, it is not surprising that the skills of the IT architect are uncharted.

IT architecture, scope, and design as strategic resources constituting core IT capabilities have been considered [25] pp. 18-19. These capabilities are characterized by high technical skills, medium interpersonal skills, and low to medium business skills. Architect skills embedded in a program (Site 6) that defines architecture roles in its own way (EA manager, EA strategist, EA designer, EA program architect, and EA administrator) were examined [87]. A matrix that matches competencies to tasks was also presented in [87], although the tasks were based on a program (Site 6). The processes and products were decoupled from other well-known frameworks. Most competencies were personal traits, individual behaviors, and attitudes (e.g., flexibility, creativity, ambition, stress resistance, and analytical ability). These skills are soft, hard to measure, and of limited usefulness. The methods, standards, social skills, and types of technical and business knowledge required were more relevant. 
A framework (Site 8) defined 102 IT skills of which 11 skills relate to architecture. Nine skills denote design, one skill is solution architecture, and one skill is enterprise and business architecture. However, the presentation of those skills includes role and task descriptions over multiple levels.

Similar to the program (Site 6), some authors classified architects in their own way. For instance, in [89] architects were subdivided into three groups: enterprise, application, and infrastructure. In addition to characterizing enterprise, segment, and solution architects, the TOGAF framework [81] introduced the roles EA manager, EA technology, EA data, EA applications, etc., in the skill framework section. The architecture skill framework [81] defined four levels of proficiency: Background should be provided, if required (level 1), Awareness for understanding issues, implications, and further steps (level 2), Detailed knowledge for professional advice and ability to integrate in architecture design (level 3), and Expert knowledge and experience (level 4). The framework [81] also defined seven skill areas, each consisting of five to 17 specific skills. It [81] provided comprehensive maps by assigning a proficiency level to each role and to a specific skill. To better capture the skill requirements for each role, average proficiency values were calculated over all skills within one skill area. Table 1 exhibits mean proficiency values for the different types of architects. The skill sets EA technology, EA data, and EA applications are not significantly different. The EA manager role seems to be quite far from reality because this profile plots a universal expert or a genius.

Table 1: TOGAF proficiency levels for enterprise architects (mean values over all skills per area)

\begin{tabular}{|l|l|l|l|l|l|}
\hline Skill area & \multirow{2}{*}{$\begin{array}{l}\text { No. of } \\
\text { skills }\end{array}$} & \multicolumn{4}{l|}{ Enterprise architecture } \\
\cline { 3 - 6 } & 8 & Manager & Technology & Data & Application \\
\hline Generic (lead, communication,...) & 8.00 & 3.63 & 3.63 & 3.63 \\
\hline Business, strategy, organization,.. & 11 & 3.64 & 3.27 & 3.36 & 3.36 \\
\hline Enterprise architecture & 17 & 3.82 & 3.53 & 3.47 & 3.82 \\
\hline Program/Project management & 5 & 3.60 & 3.00 & 3.00 & 3.00 \\
\hline General IT knowledge & 17 & 3.24 & 3.59 & 3.59 & 3.47 \\
\hline Technical IT skills & 13 & 3.00 & 3.92 & 3.38 & 3.31 \\
\hline Legal environment & 5 & 2.60 & 2.40 & 2.40 & 2.40 \\
\hline
\end{tabular}

Proficiency level: 1 - Background, 2 - Awareness, 3 - Detailed knowledge, 4 - Expert.

In addition to the proficiency level tables, the TOGAF framework [81] pp. 474-475 describes enterprise architect skills as follows (summary):

- $\quad$ Skills for producing designs and solutions, including requirement analysis

- Deep technology knowledge in one or several subjects and profound technology knowledge over a wide range of platforms and systems

- Knowledge of enterprise architecture methods

- Project experience from design, development, test, implementation, and operation

- Communication, relationship building, leadership, and negotiation skills

- Business processes skills from one or more industries

The latter bullet points roughly fit to the facets of the IT/enterprise architect that were summarized in the previous subsection. Nevertheless, these are shown on high level lacking detail. Thus far, theoretical elaboration has provided a better understanding of IT architecture as a discipline and of the types, tasks, and skills of IT architects. However, those considerations are diverse and have apparently not arrived in the real world yet. To understand what detailed tasks and skills are demanded in practice, I asked the following research questions: What are the tasks of IT architects? What skills are required for IT architects? The breakdown of skills per TOGAF skill area [81] pp. 468-471 was used as coding scheme to validate its closeness to practice.

\section{Methodology}

The methodology section describes in detail how data was gathered and evaluated. It starts with outlining the assumptions and the approach, then content analysis technique is characterized by elaboration on sampling and coding. 


\subsection{Assumptions and Approach}

Philosophical assumptions underpin the strategy and methodology of a researcher [72]. The focus of this study was the usefulness of future practice in the domain of IT architecture. Pragmatist ontology, epistemology, and axiology focus on improving practice and on supporting action [72] p. 152. In this study, pragmatist methods and techniques were applied as they fit the purpose [17] p. 28. In addition, data collection and numerical evaluations sought objectivism, whereas interpretivist philosophy was adopted when the meanings were discussed and the context was extended.

In this study, the research approach was inductive. As the study was exploratory, propositions were developed, and theories were built after the data collection and analysis [86] p. 24. This research explored significant roles in view of enterprise IT planning by analyzing the content of job descriptions. As there were no previous studies on this phenomenon, inductive content analysis was an appropriate methodology [22] p. 107. The purpose of content analysis is to provide explanations and to create categories by exploring textual data in inductive ways [64] p.114.

Document content analysis is a means to systematically and objectively assess written data to describe a phenomenon. Inferences about intentions and context may be made [20] p. 314. The context is the conceptual environment of a text and encompasses the researcher's knowledge that she or he applies to the investigated text. The context might take various forms, such as scientific theories or argued propositions [51] p. 51. In the present study, the data were coded and categorized, characteristics of the content and their significance were identified. The texts of the tasks and skills within the job advertisements were evaluated with an open mind to recognize meaningful subjects that help answer the research questions [6] p. 10.

\subsection{Content Analysis of Job Descriptions}

Although classified as secondary data, job descriptions are the best data source for gaining an understanding of job requirements. Job descriptions express the thought-out expectations that managers and human resource experts have for new hires. Tasks and skill requirements are frequently collected in collaboration with other experts and are aligned to the enterprise's recruiting principles. Thus, codes from job ads are richer than primary data from interviews of individuals who probably do not bear in mind the whole extent of their job role at the time of an interview.

To set the parameters for the content analysis design, I searched for similar studies as reference points. Surprisingly, few content analyses have been carried out on job ads. I found 11 comparable content analyses that were published within the last 15 years that refer to competencies of various job roles within the fields of IT management. Table 2 provides an overview of those studies. The main attributes of those studies are the sample size, geographic job market, data sources, ways to code, development of categories, and number of categories.

The number of analyzed job ads varied broadly from 56 to 2297. Many studies with large sample sizes applied content analysis software and focused on counting keywords and phrases. Ten of the 11 studies concentrated on the job market within one country. In addition, the number of data sources was limited. Most studies relied on one source, for example, a public job website. Printed job ads have widely been substituted by postings on Internet job portals; thus, paper-based job ads did not appear in recent studies. Another feature of job content analysis is the number of job categories to which the hits were allocated. Eight studies were in the range between seven and 24 categories; only one was far higher (64). Two studies did not provide categories at all but presented their results in different ways, one as patterns and the other as exemplary job descriptions. The way category tables were built is interesting. They may have been taken from literature analysis or developed from data that had been gathered, or from a combination of the two.

\subsection{Sampling}

There is no general rule for sample sizes in content analysis. Determining sampling strategy and size is up to the researchers as they assess adequateness for purpose [71]. The sample size should be sufficient to make analytical conclusions from results [10] to present outcomes for new insights [71] or to meet information requirements to solve the research problem [6]. The aim is to gain deeper understanding of the architect role by analyzing task and skill descriptions from job ads. I was interested in the types and accumulation of responsibilities and skills. Thus, sampling was purposeful; that is, the sample was selected on job portals to best answer the research questions [72] p. 301. In qualitative research, sampling may stop at saturation, the point at which new information no longer emerges in the data collection (Site 4). After several thorough iterations with continually optimized coding schemes, the saturation point was reached. In the last cycle, no categories needed to be added, as all meaning units were unequivocally allocated to reorganized categories. Moreover, patterns were detected based on frequencies per category. Finally, meaningful skill categories were grouped from aggregation [40] p. 1279.

The first sample was retrieved from stepstone.de, ranked by Germany's leading economy newspaper Handelsblatt as among the top five digital brands in Germany (Site 9). On 24 September 2018, stepstone.de displayed 301 job ads with the search term Architect in the title. The country search options were All Germany, All Switzerland, All Austria, 
All Western Europe, and All Eastern Europe. The language of the job ad was English; the category was set to IT. In the output list of 301 items, the job titles changed, and the search term Architect was not included after 74 job ads. Therefore, the demarcation point of sample A (see Appendix A) was determined.

Sample A from stepstone.de was limited in two ways. One idea was to cover perspectives on architects' roles from several countries, but the sample mainly included firms based in Germany. Of particular interest was the role of the enterprise architect, but only five job titles contained the string Enterprise Architect. Therefore, because of those constraints, another sample B (see Appendix B) was downloaded on 1 October 2018 from www.totaljobs.com, a leading job portal that is hosted in the United Kingdom (Site 11). I searched for the exact sequence Enterprise Architect in the job titles. The portal responded with 1640 job ads, but the title changed after 51 job ads.

Table 2: Studies within the last 15 years that applied content analysis to technical job ads

\begin{tabular}{|c|c|c|c|c|c|c|c|c|}
\hline Ref. & Year & Roles & $\begin{array}{l}\text { Sample } \\
\text { size }\end{array}$ & Countries & Data sources & Coding & $\begin{array}{l}\text { Number of } \\
\text { categories }\end{array}$ & $\begin{array}{l}\text { Development } \\
\text { of categories }\end{array}$ \\
\hline [26] & 2004 & IT professionals & 2297 & USA & $\begin{array}{l}\text { Three print } \\
\text { media, } \\
\text { monster.com }\end{array}$ & $\begin{array}{l}\text { Manual } \\
\text { (single) }\end{array}$ & $\begin{array}{l}7 \text { non-technical } \\
\text { skills }\end{array}$ & Literature \\
\hline [46] & 2004 & $\begin{array}{l}\text { Early career IT } \\
\text { graduates }\end{array}$ & 400 & Australia & $\begin{array}{l}\text { Online (not } \\
\text { specified) }\end{array}$ & Software & $\begin{array}{l}17, \text { six } \\
\text { subcategories }\end{array}$ & $\begin{array}{l}\text { Literature, } \\
\text { data analysis }\end{array}$ \\
\hline [61] & 2009 & $\begin{array}{l}\text { Metadata } \\
\text { professionals }\end{array}$ & 107 & USA & AutoCAT & Software & $\begin{array}{l}22 \text { responsibilities; } \\
18 \text { qualifications / } \\
\text { skills }\end{array}$ & $\begin{array}{l}\text { Pre-study, } \\
\text { literature, } \\
\text { authors }\end{array}$ \\
\hline [62] & 2009 & $\begin{array}{l}\text { Digital } \\
\text { cataloging }\end{array}$ & 349 & USA & AutoCAT & Software & 21 skills & $\begin{array}{l}\text { Pre-study, } \\
\text { literature, } \\
\text { authors }\end{array}$ \\
\hline [75] & 2010 & $\begin{array}{l}\text { Operational } \\
\text { research }\end{array}$ & 1000 & USA & $\begin{array}{l}\text { Monster.com, } \\
\text { Hotjobs.com, } \\
\text { OR/MS Today }\end{array}$ & Software & $\begin{array}{l}11 \text { top-level skills, } \\
49 \text { sub-categories }\end{array}$ & Data analysis \\
\hline [2] & 2013 & $\begin{array}{l}\text { Project } \\
\text { managers }\end{array}$ & 762 & $\begin{array}{l}\text { Australia / } \\
\text { N. Zealand }\end{array}$ & seek.com & $\begin{array}{l}\text { Manual } \\
\text { (single) }\end{array}$ & $\begin{array}{l}\text { Top } 10 \\
\text { competences }\end{array}$ & $\begin{array}{l}\text { Literature, } \\
\text { data analysis }\end{array}$ \\
\hline [76] & 2013 & $\begin{array}{l}\text { Construction } \\
\text { engineers }\end{array}$ & 60 & Germany & VDI job portal & Manual & 64 competences & Literature \\
\hline [11] & 2015 & $\begin{array}{l}\text { Technical } \\
\text { communicators }\end{array}$ & 914 & USA & Monster & No info. & $\begin{array}{l}18 \text { professional } \\
\text { competencies }\end{array}$ & $\begin{array}{l}\text { Literature, } \\
\text { data analysis }\end{array}$ \\
\hline [13] & 2015 & $\begin{array}{l}\text { Performance } \\
\text { consultants }\end{array}$ & 56 & Canada & $\begin{array}{l}\text { Recruiting } \\
\text { partner }\end{array}$ & $\begin{array}{l}\text { Manual } \\
\text { (team) }\end{array}$ & $\begin{array}{l}\text { Patterns were } \\
\text { presented. }\end{array}$ & Literature \\
\hline [15] & 2017 & $\begin{array}{l}\text { Data } \\
\text { professionals }\end{array}$ & 70 & USA & $\begin{array}{l}\text { Five online job } \\
\text { lists }\end{array}$ & Software & $\begin{array}{l}\text { Exemplary job } \\
\text { descriptions } \\
\text { created }\end{array}$ & Data analysis \\
\hline [27] & 2018 & $\begin{array}{l}\text { Big data } \\
\text { professionals }\end{array}$ & 1216 & USA & Indeed & Software & $\begin{array}{l}24 \text { concept } \\
\text { categories }\end{array}$ & $\begin{array}{l}\text { Data analysis } \\
\text { (pile sorting) }\end{array}$ \\
\hline
\end{tabular}

Both samples, A and B, comprised 125 job ads from which I excluded 13. Seven were duplicates, and two job ads were project managers from the description although the titles contained the term Architect. I found the same effect in two ads for programmers. Finally, I removed one job ad because it was written in German, and another ad redirected to the company's own job portal, which was empty. From remaining 112 job ads, 13 were for contractors and 99 for permanent employees. Seventy-seven jobs were directly advertised by firms that wanted to engage the architect, while 35 jobs came from agencies. In addition, $29.5 \%$ of the job ads originated from IT vendors or IT service providers; they take the seller perspective. The 112 examined job ads provided 2438 meaning units that were assigned to 37 task categories and 49 skill categories bundled in seven skills category groups.

\subsection{Coding}

The units of analysis were descriptions of the skill requirements and the tasks within the downloaded job ads. I started with the directed content analysis approach [40] and took codes from literature before the data analysis. I selected skill definitions from the TOGAF framework [81] as the coding foundation [81] pp. 468-471. I abandoned this approach after tests with 16 job ads. Forty-eight of 76 skills from the framework [81] were not matched at all. In addition, much information from jobs ads could not be allocated to the predetermined coding scheme. Thus, the skill set from the framework [81] was insufficient to reflect the real demand. As an alternative, I changed the coding approach to 
conventional content analysis that derives codes from data. Starting from scratch without any code, I established the new coding scheme during data analysis as codes emerged until saturation [40] p. 1286. In contrast to a priori coding that uses categories from theory, emergent coding develops categories out of data [77] p. 2. I followed the step model from an online source [54] for developing inductive categories. I developed categories from observation during analysis of the first 40 job ads (sample A) and then refined and applied the categories to the rest of sample A (72 job ads in total). For consistency, I reapplied the reworked coding scheme to the first 40 job ads from sample A. By analyzing sample B, the coding scheme was extended. Again, I reorganized the coding scheme to sharpen the codes for activities (e.g., architecture vs. design, technical vs. organizational, and high level vs. detailed design). All job ads (112) were reanalyzed on the final coding scheme.

The trade-off between reliability and level of interpretation was discussed in relation to ways to code, either latent or manifest [20], [33], [72]. The researcher can select between these approaches prior to data analysis [85] p. 401; both ways deal with interpretation [33]; there are no strict boundaries. The manifest way could be positivistic and highly reliable by counting fixed keywords but would neglect information that is valuable to better understand the role and skills of the architect. My approach could be designated as latent with little interpretation or as manifest with high interpretation. To explore the roles of IT architects, I allowed for lower reliability for the sake of interpretation. However, I claimed to cover every meaning out of a context unit that were bullet points or sentences within the task or skill descriptions. By interpreting them, I covered relevant synonyms. They are not only single words but also diverse expressions. For example, the context units You verify that the software architectural design maps relevant requirements on to software components and Verify technical solutions with stakeholders such as Network or Security team... were recorded in the category Ensure quality because verification of requirements is a quality measure in project management [66]. As other examples, writing codes was a hit for the task category Programming, and Identifying technical solutions based on.... required capabilities was recorded in the task category Define/specify requirements.

A single context unit may contain one or more meaning units. The meaning units were allocated to categories. Each meaning unit must be allocated to exactly one category. For instance, the task Align the solution being recommended with the client strategic direction, managing exceptions, and effectively communicating solutions and their justification to relevant stakeholders includes several meanings and fit four categories: Communicate...., Align with other units/departments, Ensure compliance with business/business strategy, and Support customer.

Ideally, tasks and responsibilities should fully correspond within job ads. In many cases, they did not match or only in parts. I did not make conclusions from tasks to skills and versa. It would have required too much interpretation and would have distorted the results as a whole. In some ads, skills were presented in the task/responsibility section, and in other ads, tasks were listed under skills. Those meaning units were recorded because they did not need to be interpreted; they were just placed in the wrong section of the job ad.

I wanted to find out the essential skills of IT architects. Therefore, I did not consider optional skill requirements that were expressed in different terms, such as is a plus, bonus points, preferred, is an advantage, or are beneficial. I also skipped requirements for personality (e.g., style, cognitive abilities, and work attitudes). Individual traits like flexibility, result orientation, commitment, resilience, creativity, and so on are expected anyway. Skill descriptions were sometimes strange, such as Ability to understand detailed impact while keeping the eye on the big picture as well as to balance what is right with what is realistic. Regarding tasks, I ignored bland, expressionless items such as Help shape the future, Create something new, Be innovative, etc.

\section{Findings}

To better understand the ambiguous role of the IT architect, the contents of job advertisements were investigated by identifying meaning units in skill and task descriptions and allocating them to categories. As the categories were developed from the collected data, the category tables for architect tasks and skills are key outcomes and responses to research question 1 (subsection 4.2 Architect Tasks) and research question 2 (subsections 4.3 Architect Skills in Detail and 4.4 Architect Skills on Aggregated Level).

In addition, the frequencies of the job ads for a category were evaluated. Frequency is a recommended technique for content analysis [65], [77]. Frequencies are presented in the percentage of job ads that contain at least one meaning unit for that category. The quantities indicate the magnitudes and sizes of the categories and may be expressed relative to a sample [51] p. 103.

\subsection{Job Titles of Architects}

The sampled IT architect ads had various titles that reflect the inconsistency of the IT architect's role in general. The search term Architect provided 59 different titles out of 66 job ads in sample A. However, some groups of architects were recognized based on common parts in titles, namely, enterprise architects, software architects, solution architects, system architects, data architects, and security architects. After comparing the tasks and skills, I subsumed the latter three groups under the type Solution Architect. Roughly speaking, those architects pursue similar goals, in essence designing IT solutions, but focus on different technologies and systems. Thus, 46 architects were assigned to one of 
three groups. The remaining 20 samples could not be assigned based on their titles. These samples required examination of the job descriptions for allocation to the appropriate type.

From those examples and from the exclusions mentioned previously, it can be concluded that the titles of architects alone are not only insufficient but also misleading for capturing the particular architect role. All architecture assignments of the samples were reviewed, and the samples were reassigned if necessary. Decisive for allocation of samples to types were the task descriptions in the job ads, not the titles. For example, job ad no. 51 from sample B with the title Data Architect - Database Enterprise Architect - Information describes responsibilities for appropriate architecture and for design of end-to-end solutions. Therefore, this job was assigned to the solution architect group. Table 3 shows the allocation of the samples to the architect types. Tables in the appendix provide overviews of all sampled jobs and their allocation to architect types.

\subsection{Architect Tasks}

Thirty-seven task categories were defined from the data collection and iterative reorganization. Percentage shares of job ads, which contained meaning units for those categories, were evaluated for each architect type. Thus, the main emphasis for each architect type became more transparent. The solution architect was selected as the reference task profile to compare deviations of percentage shares with tasks profiles for enterprise architects and solution architects (Table 5). The tasks in table 5 were sorted based on the percentages for solution architect in descending order. To better detect the key differences among the architect types, I marked deviations of greater than $15 \%$ with a dark blue cell background and differences greater than $-15 \%$ with a bright blue cell background.

Table 3: Number of job ads per architect type within samples A and B

\begin{tabular}{|c|c|c|c|}
\hline Set & Architect type & Number & Total \\
\hline A & Enterprise & 9 & \multirow{2}{*}{54} \\
\hline B & Enterprise & 45 & \\
\hline A & Solution & 13 & \multirow{6}{*}{43} \\
\hline$A$ & Solution (Data) & 7 & \\
\hline B & Solution (Data) & 1 & \\
\hline A & Solution (System) & 7 & \\
\hline A & Solution (Security) & 4 & \\
\hline A & Solution (Other) & 11 & \\
\hline A & Software & 10 & \multirow{2}{*}{15} \\
\hline A & Software (Other) & 5 & \\
\hline
\end{tabular}

\subsection{Architect Skills in Detail}

Forty-nine skill categories were identified and arranged in seven skill category groups. Table 6 shows the number of job ads matching the respective category (with at least one meaning unit) relative to the total sampling size as the percentage. Of all samples, teamwork (51.8\%) and communication $(40.2 \%)$ are the most dominant social skills. Profound knowledge of systems and technologies are in high demand (70.5\%). In comparison, knowledge of vendors' products and services is of secondary importance (21.4\%). Methods for development, engineering, and design are more often stated $(50.9 \%)$ than methods for architectures $(38.4 \%)$. There is low demand for frameworks for architecture management, project management, or IT management $(<10 \%$ each). Meaning units for business and strategy knowledge were included in $22.3 \%$ of the job ads. The significance of legal and regulatory knowledge is low (6.3\%).

\subsection{Architect Skills on Aggregated Level}

Similarities among skills categories were sought to help to describe the observed phenomena by second-order analysis [30] p. 20. Skills were aggregated up to the skill category group level (second-order themes) and compared between architect types. Table 4 exhibits the relative numbers of job ads that contained at least one meaning unit per skill category group (samples A and B; per architect type). All types of architects must provide social, technical, and methodology skills. However, the profile of the enterprise architect differs in three ways. First, business skills and knowledge of frameworks and standards are more often in demand. Second, the need for legal/regulatory knowledge 
is noticeably beyond the average. Third, requests for social skills are lower than for the solution architect (-16.6\%); the difference between both types in terms of technical knowledge is even greater $(-18.1 \%)$.

Table 4: Percentage of job ads that contained meaning units for skill categories groups

\begin{tabular}{|l|l|l|l|l|}
\cline { 3 - 5 } \multicolumn{1}{c|}{ Skill category group } & \multirow{2}{*}{$\begin{array}{c}\text { All Architects } \\
(112)\end{array}$} & \multicolumn{3}{|c|}{ by Architect type } \\
\cline { 3 - 5 } & 82.1 & Enterprise (54) & Solution (43) & Software (15) \\
\hline Social & 89.3 & 79.1 & 90.7 & 86.7 \\
\hline Technical knowlegde & 91.1 & 90.7 & 97.7 & 93.3 \\
\hline Methods & 28.6 & 38.9 & 88.4 & 93.3 \\
\hline Standards / frameworks & 39.3 & 51.9 & 34.9 & 20.0 \\
\hline Business & 8.9 & 11.1 & 7.0 & 20.0 \\
\hline Certifications & 6.3 & 11.1 & 2.3 & 6.7 \\
\hline Legal / regulatory & & & 0.0 \\
\hline
\end{tabular}

Table 5: Tasks that were listed in job ads (in percent)

\begin{tabular}{|c|c|c|c|}
\hline Architect tasks & $\begin{array}{l}\text { Enterprise } \\
\text { Architect }\end{array}$ & $\begin{array}{l}\text { Solution } \\
\text { Architect }\end{array}$ & $\begin{array}{l}\text { Software } \\
\text { Architect }\end{array}$ \\
\hline Collaborate with other roles / organizational units & 40.7 & 62.8 & 73.3 \\
\hline $\begin{array}{l}\text { Create / propose designs, developments,solutions, products, } \\
\text { applications, SW }\end{array}$ & 29.6 & 58.1 & 40.0 \\
\hline Counsel / consult / advise stakeholders & 46.3 & 55.8 & 20.0 \\
\hline Lead team / function & 48.1 & 51.2 & 26.7 \\
\hline Support projects & 50.0 & 46.5 & 13.3 \\
\hline Create / propose / manage architecture & 44.4 & 46.5 & 73.3 \\
\hline Define / specify requirements & 29.6 & 46.5 & 40.0 \\
\hline Ensure compliance with business / business strategy & 57.4 & 41.9 & 26.7 \\
\hline $\begin{array}{l}\text { Create / review / enhance / maintain architecture strategy, framework, } \\
\text { approaches, methods, governance, policies, principles, rules, } \\
\text { processes, tools }\end{array}$ & 61.1 & 37.2 & 40.0 \\
\hline Support implementation / deployment / roll-out & 20.4 & 37.2 & 20.0 \\
\hline Integrate (software, systems) & 9.3 & 32.6 & 40.0 \\
\hline $\begin{array}{l}\text { Create / review / enhance / maintain design or development guidelines, } \\
\text { best practices, concept, standards, rules }\end{array}$ & 31.5 & 30.2 & 33.3 \\
\hline Research market / technology / trends / product & 16.7 & 30.2 & 40.0 \\
\hline Optimize / improve efficiency (beyond architectural concepts) & 27.8 & 25.6 & 26.7 \\
\hline Ensure quality & 20.4 & 25.6 & 33.3 \\
\hline Communicate... & 18.5 & 25.6 & 13.3 \\
\hline Support customers & 24.1 & 23.3 & 6.7 \\
\hline $\begin{array}{l}\text { Review (assess, validate,....) / Decide designs, developments, } \\
\text { solutions, products, applications, SW }\end{array}$ & 25.9 & 20.9 & 20.0 \\
\hline Document (create, update), artifacts & 14.8 & 20.9 & 20.0 \\
\hline Provide trainings / presentations & 3.7 & 20.9 & 6.7 \\
\hline Develop / maintain roadmap / product strategy / IT strategy & 51.9 & 18.6 & 20.0 \\
\hline Align with other units/departments & 22.2 & 18.6 & 13.3 \\
\hline Create / maintain / enhance platforms & 14.8 & 18.6 & 20.0 \\
\hline Moderate workshops / meetings & 3.7 & 16.3 & 13.3 \\
\hline Ensure consistency / alignment / adherence / compliance to standards & 22.2 & 14.0 & 13.3 \\
\hline Identify and report, risks / issues; maintain risk logs & 5.6 & 14.0 & 6.7 \\
\hline Support operation & 5.6 & 14.0 & 0.0 \\
\hline Support sales / proposals & 7.4 & 11.6 & 0.0 \\
\hline Test solution & 0.0 & 11.6 & 6.7 \\
\hline $\begin{array}{l}\text { Define reusables, blueprints, building blocks, patterns, templates, } \\
\text { generic HW, applications, references }\end{array}$ & 29.6 & 9.3 & 13.3 \\
\hline Create models & 29.6 & 9.3 & 6.7 \\
\hline Research architecture, prototype & 14.8 & 9.3 & 6.7 \\
\hline Support transformations & 14.8 & 9.3 & 6.7 \\
\hline $\begin{array}{l}\text { Purchase / procure / source, e.g., infrastructure, assets, tools; manage } \\
\text { vendors }\end{array}$ & 13.0 & 9.3 & 0.0 \\
\hline Plan migration / implementation & 11.1 & 7.0 & 13.3 \\
\hline Manage life cycle & 3.7 & 7.0 & 0.0 \\
\hline Build / maintain relationships & 7.4 & 4.7 & 26.7 \\
\hline
\end{tabular}


Table 6: Percentage of job ads containing meaning units for skills

\begin{tabular}{|c|c|c|}
\hline \multirow[t]{13}{*}{ Social } & Teamwork, interpersonal skills & 51.8 \\
\hline & Communication (general) & 40.2 \\
\hline & International work / cultural awareness / intercultural cowork & 25.9 \\
\hline & Leadership, coordination & 25.0 \\
\hline & Documentation / technical writing & 16.1 \\
\hline & Presentation (explain, make understood) & 14.3 \\
\hline & Customer (value) delivery / facing / relationship & 13.4 \\
\hline & Interdisciplinary / cross-functional & 11.6 \\
\hline & Moderation & 8.9 \\
\hline & Stakeholder management & 8.0 \\
\hline & Influencing & 5.4 \\
\hline & Relationship building & 4.5 \\
\hline & Negotiation & 1.8 \\
\hline \multirow[t]{9}{*}{ Technical knowlegde } & System knowledge / technologies & 70.5 \\
\hline & Programming, -kits & 37.5 \\
\hline & Specific IT processes / frameworks & 26.8 \\
\hline & Product knowledge (incl. services) & 21.4 \\
\hline & Industry-specific IT concepts / models / systems & 19.6 \\
\hline & Platforms, operating systems & 4.5 \\
\hline & Technology standards & 3.6 \\
\hline & Security & 1.8 \\
\hline & Other & 13.4 \\
\hline \multirow[t]{13}{*}{ Methods } & SW / product development / engineering / design & 50.9 \\
\hline & SW / system / solution architecture & 38.4 \\
\hline & Agile development & 32.1 \\
\hline & Standards, principles, design patterns, methods, best practices & 30.4 \\
\hline & Tools & 20.5 \\
\hline & Project / program management / transformation & 18.8 \\
\hline & Requirements management & 18.8 \\
\hline & Operations & 14.3 \\
\hline & Testing & 13.4 \\
\hline & Quality & 13.4 \\
\hline & Enterprise architecture & 9.8 \\
\hline & Implementation / deployment & 7.1 \\
\hline & Integration & 4.5 \\
\hline \multirow{4}{*}{$\begin{array}{l}\text { Standards / } \\
\text { Frameworks }\end{array}$} & Project management, e.g., PMI & 8.0 \\
\hline & Architecture management, e.g., TOGAF & 6.3 \\
\hline & IT management, e.g., ITIL & 4.5 \\
\hline & Other & 17.0 \\
\hline \multirow[t]{7}{*}{ Business } & Business / strategy & 22.3 \\
\hline & Process management / design / modeling & 10.7 \\
\hline & $\begin{array}{l}\text { Cost, quality, performance, metrics, planning, organization, } \\
\text { decision-making.... }\end{array}$ & 10.7 \\
\hline & Market / product / technology trends & 9.8 \\
\hline & Presales / vendor selection / consulting & 9.8 \\
\hline & Industry-specific (non-IT) & 4.5 \\
\hline & Business case & 2.7 \\
\hline \multirow[t]{2}{*}{ Certifications } & Methods & 3.6 \\
\hline & Vendor certifications & 8.0 \\
\hline \multicolumn{2}{|l|}{ Legal / regulatory } & 6.3 \\
\hline
\end{tabular}

\section{Discussion}

The following section proposes and sketches three main types of IT architects and elaborates on characteristics in ecommerce projects to identify special attributes of e-commerce architects. The digital architect is another upcoming role that is outlined here. Moreover, constraints of this study and ideas for future research are briefly presented in this discussion part.

\subsection{Tasks and Skills from Architecture Frameworks are Disconnected from Practice}

The collected data reflect the confusion about IT architecture roles. Titles, tasks, and skills within job ads were numerous and did not adhere to any framework or standard. However, patterns were recognized, and types of architects were identified whose attributes are in line with suggestions from the literature. Many standards and frameworks present EA processes, roles, and definitions in useful ways. But there are too many competing frameworks, most of which are very comprehensive comprising several hundred pages. In addition, terms and concepts are not aligned to IT frameworks that take business or project perspectives. Consequently, IT professionals struggle to apply EA frameworks, which was also reflected in this study. Although methodology skills were in very high demand, only a 
few jobs required knowledge of or certificates for a particular framework, such as [66] or [81]. The study also showed that the widely used TOGAF framework [81] does not mirror the roles as searched on labor markets. Segment architects were not requested at all. The job types EA manager, EA data, EA technology, and EA application were neither advertised nor echoed in the contents. Even the set of 76 skills in the TOGAF framework [81] was not suitable as the coding scheme for analyzing the job ads.

\subsection{Typology of IT Architects}

As displayed in the findings section and supported by the literature, three types of architects are proposed: enterprise architect, solution/system architect, and software architect. The following paragraphs summarize their key attributes.

The enterprise architect has a strong strategic orientation. This role is key for IT-business alignment by defining appropriate IT strategies and developing technology roadmaps. Moreover, governance of architecture is central by creating and managing frameworks, policies, processes, guidelines, standards, etc. More than any other role, enterprise architects are dedicated to modeling and defining reusable blueprints, building blocks, and templates. Enterprise architects are leaders who collaborate with various roles and consult stakeholders. An enterprise architect can also create and design solutions and specify requirements but at a higher level and to a lower extent than the solution architect.

Solution/system architects create detailed designs and develop solutions by collaborating with diverse roles and by advising various stakeholders. These architects take on leadership and support projects. In contrast to enterprise architects, solution architects are more oriented toward specifying requirements, supporting implementations, and integrating systems. Solution architects also provide more training and presentations. The two terms, system and solution, describe technical segments of the overall architecture; they can be used interchangeably.

Social activities, such as cooperation, teamwork, and relationship building, are essential for software architects, but leadership, consultancy, and customer/project support were mentioned less frequently. Links to strategy and implementation are not essential. The focus of software architects is creating and managing the software architecture within the development team and liaising with other organizational units.

This typology is compatible to various frameworks. For instance, an online source [73] pp. 5-6 applied identical categories for IT architects. The framework [41] distinguishes enterprise architecture from other architectures in the same sense. The hierarchical EA model from a framework (Site 3) also fits the suggested types: business architecture and information architecture can be assigned to the enterprise architecture role, data architecture and system architecture match the solutions architect role, and software application architecture is self-explanatory. The framework in [8] p. 221 relates EA to the structure of the organization, while system architects and engineers deal with product and services. Finally, the framework [19] p. 15 portrays EA as strategic at the departmental level, whereas systems architecture is closer to implementation and operation.

\subsection{IT Architects in E-Commerce Projects}

E-commerce projects combine special attributes that influence the IT architect role. These features are worked out first, then the consequences are mirrored on the e-commerce architects' function and the associated skills.

\subsubsection{Characteristics of E-Commerce Architectures}

Business services are progressively turning into electronic services and e-commerce is decisive this way [14] p. 575. E-commerce markets are growing above average in contrast to conventional retail business [3]. By reason of ecommerce significance, the discussion is extended to specific features of e-commerce architecture and to according skills and tasks.

E-commerce denotes product-related transactions over networks between the enterprise and its customers, suppliers, and partners [58] p. 674. Electronic inter- or intraorganizational exchanges are facilitated by dedicated technologies [70]. E-commerce systems integrate several electronic methods for information display, transmission, and processing [68] p. 79, p. 271. These e-commerce systems enable dealing via the Internet [78] by using web Sites [1].

As the Internet is providing innovative ways to make business, novel job descriptions appear such as the "web architect" [1] p. 29. However, the role of the e-commerce architect has not been defined in practitioner frameworks yet. The framework [81] presents numerous architect roles but none for e-commerce. Framework [81] and skill framework (Site 8) do not even mention e-commerce as a skill type, although special skills are required for planning of e-commerce solutions. The literature neglects the e-commerce architect as well. For example, journal paper [60] described a design/development methodology for service-oriented architectures (SOA) without including the architect role; just designers and developers were considered.

The tasks of IT architects in e-commerce context are worth to be investigated because e-commerce developments distinguish from other kinds of IT projects. Conference paper [78] displayed differences between conventional IT 
developments and e-commerce projects from reviewing the literature. The authors noted the subsequent key differences:

- Stakeholder groups are broader, and skills are more diversified

- Requirements and scope are more volatile

- Life cycles of applications and development timeframes are shorter

- Development processes are less rigor and methods are more iterative

In the following, three more attributes of e-commerce, relevant to IT architects' tasks and skills, are highlighted: multitier architecture, hybrid development approach, and service paradigms. The e-commerce architect role was compared to previous architect types by aid of extra samples.

\subsubsection{Multi-Tier Architecture}

The literature and some IT vendors suggest viewing e-commerce architecture on distinct levels. Yet, the levels are defined in various ways. The paper [35] views e-commerce architecture on three tiers to cope with complexity of the enterprise's IT infrastructure. These tiers comprise the clients' computer systems, the backend with software applications, and the intermediate level for business transactions. The article [56] describes multi-tier e-commerce applications based on the Java platform consisting of the client tier (e.g., for HTML support), the middle tier (i.e., Java server), and the back-end tier (i.e., enterprise database server). Author [47] extents the stack of layers for e-commerce applications to six in total, including network, security, and data brokerage. Paper [49] also takes the idea of information brokerage, i.e., inter-application communication, in a three-level concept for IT architectures in e-commerce enterprises. The other two levels refer to SOA for seamless integration of manifold IT components and to cloud computing for flexible services. IBM's e-commerce reference architecture (Site 7) displays the cloud as core domain between the public network and the enterprise network. The design guide from Cisco Systems [88] p. 121 defines ecommerce as a module in the overall architecture consisting of servers, security devices, and switches for data transport. So, e-commerce architecture is mostly subdivided into three distinct domains or levels. I go along with the layer model from research paper [3] p. 42 that concentrates on e-commerce architecture to mirror requirements for IT resources. The business layer represents enterprise functions by aid of models and process descriptions; the technology layer contains hardware, network, infrastructure, cloud, middleware, basic services, etc.; the application layer relates to software development.

\subsubsection{Hybrid Development Approach}

The e-commerce architect must oversee all three architectural layers and manage the development towards an integrated solution. Development approaches differ by layer. The building of IT infrastructures on the technology layer typically uses the traditional predictive approach [28], whereas software developments on the application layer use agile methodologies such as scrum (Site 1). Tailoring of scrum methodology for e-commerce software development may even improve quality and shorten project duration [37]. The hybrid approach combines agile and predictive methods [66] p. 19 and must be aligned with project management [34].

\subsubsection{Service Paradigms}

E-commerce architecture is often regarded in context with service paradigms such as SOA and cloud computing [3], [49], (Site 7) that an architect must understand and incorporate if needed. "SOA is an architecture style that views IT solutions essentially as a collection of services" [44] p. 139 applied in software applications development [18]. Cloud computing provides ways to source IT capabilities as different bundles of services from external vendors. Thereby, resources are shared and delivered in various service models that differ in ownership and their operation. Cloud computing and SOA constitute perspective changes from functional IT components to service descriptions. These trends seem to simplify management of IT delivery, but architectural deliberation is still crucial [53] p. 7. Interoperability between platforms, languages, cloud infrastructures, etc. must be carefully considered. Integration could span over several providers, domains, platforms, and technology components [48] that may make architectural design complex.

\subsubsection{The E-Commerce Architect}

The title e-commerce architect is not established in practice. Only one job ad from investigated samples included both keywords (commerce, architect) in its title. Other dedicated searches on these keywords on 24. January 2019 provided only six hits on totaljobs.com and just three on stepstone.de (sample C). This time, I included German job ads on stepstone.de, since English job ads were not found there. After excluding one job ad for mobile commerce on Android smartphones, eight job ads remained for exploring patterns in their task descriptions (see Appendix C). Each task was allocated to one of three architect types as presented before. None of the job ads indicated tasks typical to the software architect. Seven out of eight job ads contained tasks from both the enterprise architect type and the solution architect type. The other job ad contained items that exclusively referred to the solution architect type. From 60 tasks, $73 \%$ were allocated to the solution architect type and $27 \%$ to the enterprise architect type. From these few examples, one may propose that e-commerce architects combine enterprise architecture and solution architect tasks with main emphasis 
on the latter role. This observation is in line with paper [53] p. 6, which stated that IT architects operate on two major levels: the enterprise level for flexibility, integration, and reuse, and the solution level for reliability, performance, and interoperability.

In summary, e-commerce architects create designs that extend over three layers as presented in article [3]. They consider strategic aspects on the business layer like an enterprise architect and perform tactical tasks like a solution architect on the infrastructure layer. Although, the e-commerce architect does not actively engage in software developments, she or he aligns activities and objectives on the application layer to the business and the infrastructure layers. These alignments need to combine and manage predictive and agile development methodologies to the hybrid approach. Table 7 displays the mapping of architect types to e-commerce architecture layers and shows the combinations relevant to e-commerce architects. Finally, service paradigms applied in e-commerce, such as SOA or cloud computing, enhance IT efficiency in total but do not reduce architectural sophistication and demand.

Table 7: Combinations of architect attributes for e-commerce projects

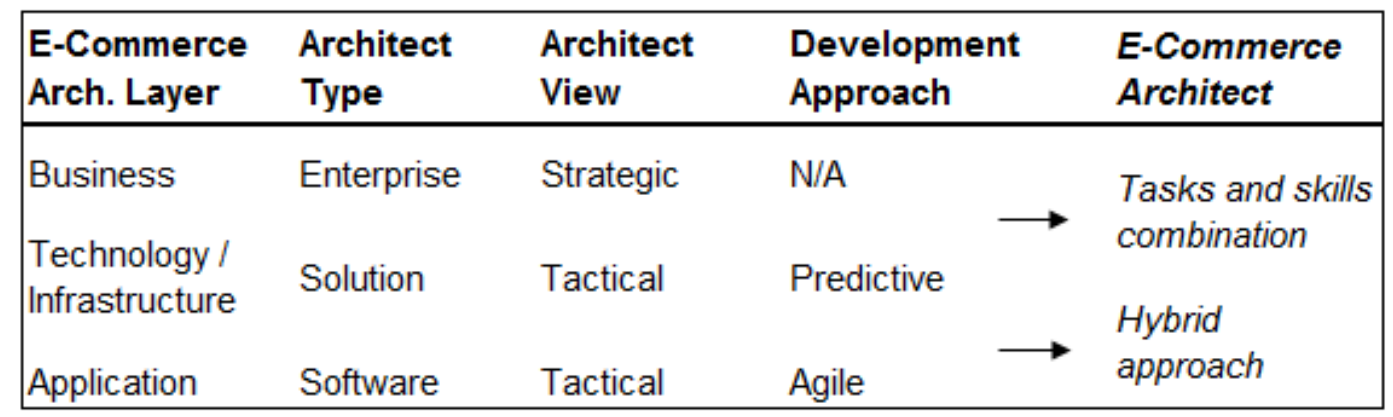

\subsection{The Upcoming Evolutionary Step: The Digital Architect}

Digital entrepreneurship is an emerging field in research and practice. Main areas of digital entrepreneurship are the generation of new business and the organization of digital innovation [23]. Digital innovations go beyond networkbased transactions from e-commerce, which concentrates on economic benefits [63]. Digital innovations utilize user data from sensors, take advantage from social trends, and create or modify business systems [29]. Digital innovations provide new values between professional stakeholders and consumers based on user-generated content [80]. Creation of value for customers are central for services that found on digital technologies [5], [9], [63], [83].

The utilization of digital chances and the management of digital innovations necessitate enhanced organizational IT capabilities [84]. Organizations engaging in digital transformations require new leadership roles and digital skills to cope with environmental changes [57]. For example, the new role of the chief digital officer (CDO) is different from the traditional function of the chief information officer; it concentrates on digital innovation. The CDO is placed between IT and marketing; he or she acts close to customers with pronounced value orientation. The CDO concentrates on projects with digital technologies; the aim is to generate novel revenue streams [84]. The role of the enterprise architect also needs to be adapted in the digital transformation context. In particular, the enterprise architect should evaluate the creation and the capture of values and observe technological progress and business trends in real-time [50]. Digital architects must make effective decisions and enable rapid solution development by employing modular services and components [50] pp. 356-357.

High innovation speed calls for potent architecture and design practices, e.g., by using standards, modules, and platforms [50], [90]. Hierarchy-of-parts architecture and network-of-patterns architecture are suggested complementary architecture approaches to increase the speed for (re)designing digital services and products [38]. Flexibility and adaptivity are critical abilities of enterprise architects in the digital transformation [92].

Beside effective methods and techniques for product/service design and the distinct customer value attitude, digital architects must lead and govern digital innovations [39], [50], [90]. Recombination of technologies and opportunities for value creation are centerpieces of digital innovation. Design recombination means connecting digital resources to create value [39]. "New opportunities can be seized by connecting smart devices, modifying business systems, and/or exploiting social trends" [29], p. VI.

Six job postings that contained the term digital in the job title were found in samples $\mathrm{A}, \mathrm{B}$, and $\mathrm{C}$. Three of them were from type enterprise architect, two jobs were from type solutions architect, and one architect job was responsible for software. Four job ads contained terms for digital technologies such as Internet of Things, cloud, big data, robotics. Valid conclusions cannot be drawn from this data. Further content analyses are recommended to identify tasks and skills that are generalizable. However, from the previous interpretations and the literature presented in this section, propositions on characteristics of digital architects can be outlined. 
Similar to e-commerce architects, digital architects combine tasks and skills from enterprise architects and solution architects. They possess deep knowledge on digital technologies, such as networks, sensors, and artificial intelligence. Like CDOs, digital architects are strongly focused on innovation and customer value creation to generate new revenue streams (cost optimization is in the scope of other architects). Creativity is needed for changing business systems by application of digital technologies and by collecting and evaluating user data. To be faster than innovative competitors, digital architects employ sophisticated and advanced design methods (e.g., modularization, recombination).

\subsection{Limitations and Future Research}

Several limitations must be considered. Searching and interpreting meaning units and allocation to categories were done by a single coder who unconsciously might have impaired the results. Weaknesses mainly stem from coding errors by altering interpretations, misunderstandings, or overseeing the codes. Two or more coders would have increased reliability. Moreover, the sample is not representative enough to generalize it to a population.

Content analysis of job ads using the same coding scheme can be continued in other countries to increase generalizability. Directed content analysis [40] can be applied by using codes and keywords from the presented schemes. A greater sample size should be chosen for job ads of e-commerce/digital architects to deeper examine these roles and according digital skills. New insights can also be gained by using other methods of qualitative research, for example, semi-structured interviews with IT managers and system engineers. Other interesting research questions can be raised about IT architects' co-operation and communication with other key roles, such as business analysts or project managers.

This exploratory and inductive study has built a nascent theory by categorization and characterization of IT architects. A subsequent intermediate theory study could empirically verify the proposed IT architect typology. Surveys and/or structured interviews among IT professionals would provide useful quantitative data for testing the results from this content analysis [21]. Both empirical building and testing of theories provide elevated scientific contributions [16].

\section{Conclusions}

IT architecture provides critical capabilities and is of strategic importance for gaining and sustaining competitive advantage. Numerous rival institutions try to enhance architecture management by publishing frameworks that are not consistent and that are insufficiently employed in the industry. The EA discipline is widely unexplored in theory and is fuzzy in practice. Moreover, previous IT architecture research neglected the role of the architect.

IT architects are decisive resources for the creation of information systems and their management over life cycles. These architects' tasks and skills were examined with job advertisements. From content analysis, three types of architects were induced that are backed by the literature. Enterprise architects align IT strategies with business and are responsible for EA methods, governance, policies, principles, processes, etc. They develop roadmaps for IT products and services, define reusable artifacts, and create structural models. Solution or system architects specify system requirements and functions as foundations for detailed solution or system designs. These architects specify hardware and software components and the interaction between them. Software architects collect and analyze software requirements and design the software accordingly.

E-commerce architecture has miscellaneous aspects. It includes three tiers (business, infrastructure, application), two different development approaches, and various service paradigms (e.g., SOA, cloud). Architects in e-commerce projects combine tasks of enterprise and solution architects, think and act strategically and tactically, and deal with the hybrid development approach. Digital architecture is an evolving discipline that extents the architecture scope on innovation, business modeling, and customer benefits. Digital architects make use of data from sensor-equipped objects that are intelligent and continuously connected via networks. Thereby, development speed and value creation are central.

All IT architects must provide high proficiency in social skills, in particular, verbal and written communication, teamwork, and leadership. In addition, system and technology knowledge is of great importance. A methodological background in engineering, designing, developing, and architecting is crucial, whereas knowledge of specific standards and frameworks is barely demanded. Business and legal knowledge is required mainly for enterprise architects.

This research evaluated data from practice and partly refutes the skills and the EA types in the leading framework TOGAF [81]. The TOGAF skill set was unsuited for directed content analysis; many EA roles were not reflected in job ads. Stakeholders dealing with IT management can gain more clarity about the core tasks and key competencies of three types of architects. The listed task and skill categories may be used as catalogs. Managers and recruiters may benefit from these catalogs by selecting needed items when creating their job ads. This research was exploratory and lacks representativeness. Directed content analysis of job ads in other countries and semi-structured interviews with architect-facing IT professionals would enhance knowledge and dissolve the fog around IT architects. 


\section{Websites List}

Site 1: Agile Manifesto

https://agilemanifesto.org/principles.html

Site 2: Enterprise Architecture Body of Knowledge http://www.eabok.org/eabok.html

Site 3: Enterprise Information Technology Body of Knowledge

http://eitbokwiki.org/Main Page

http://eitbokwiki.org/Common EIT Roles

http://eitbokwiki.org/Glossary

Site 4: Center for Innovation and Research in Teaching (CIRT) - Grand Canyon University, Arizona https://cirt.gcu.edu/research/developmentresources/research ready/qualitative/sampling

Site 5: Cisco Certified Architect https://learningnetwork.cisco.com/community/certifications/cisco certified architect/syllabus https://www.cciehof.com/stats.htm

Site 6: General Enterprise Architecting research program http://groeiplatformgea.nl/

Site 7: IBM E-Commerce Reference Architecture https://www.ibm.com/cloud/garage/files/ecommerce-high-level.pdf

Site 8: Skills Framework for the Information Age https://www.sfia-online.org/en/framework/sfia-7/a-to-z-skills-collection

Site 9: Steptone (job search portal for sample A)

https://www.stepstone.de/

https://www.stepstone.de/ueber-stepstone/press/auszeichnung/

Site 10: Systems Engineering Body of Knowledge Wiki http://www.sebokwiki.org/wiki/Physical Architecture (glossary)

Site 11: Totaljobs (job search portal for sample B) https://www.totaljobs.com/

\section{References}

[1] T. Addison, E-commerce project development risks: Evidence from a Delphi survey, International Journal of Information Management, vol. 23, no. 1, pp. 25-40, 2003.

[2] K. Ahsan, M. Ho and S. Khan, Recruiting project managers: A comparative analysis of competencies and recruitment signals from job advertisements, Project Management Journal, vol. 44, no. 5, pp. 36-54, 2013.

[3] F. Aulkemeier, M. Schramm, M.-E. lacob, and J. van Hillegersberg, A service-oriented e-commerce reference architecture, Journal of Theoretical and Applied Electronic Commerce Research, vol. 11, no. 1, pp. 26-45, 2016.

[4] W. Baets, Aligning information systems with business strategy, Journal of Strategic Information Systems, vol. 1, no. 4, pp. 205-254, 1992.

[5] A. Baird and T. S. Raghu, Associating consumer perceived value with business models for digital services, European Journal of Information Systems, vol. 24, no. 1, pp. 4-22, 2015.

[6] M. Bengtsson, How to plan and perform a qualitative study using content analysis, NursingPlus Open, vol. 2, pp. 8-14, 2016.

[7] M. van den Berg and $\mathrm{H}$. van Vliet, The decision-making context influences the role of the enterprise architect, in Proceedings of 2016 IEEE 20th International Enterprise Distributed Object Computing Workshop (EDOCW). Vienna, Austria. IEEE Computer Society, 2016, pp. 114-121.

[8] BKCASE. (2018) Guide to the systems engineering body of knowledge (SEBoK) v1.9.1, Body of Knowledge and Curriculum to Advance Systems Engineering, 2018. [Online]. Available: https://www.sebokwiki.org/w/images/ SEBoK\%20v.\%201.9.1.pdf

[9] A. Blitz, Beset by the digital revolution successful retailers embrace technology that enhances customer value, Strategy \& Leadership, vol. 44, no. 6, pp. 16-24, 2016.

[10] R. W. Brislin, Translation and content analysis of oral and written, in Handbook of Cross-Cultural Psychology, vol. 2: Methodology (H. C. Triandis and J. W. Berry, Eds.). Boston, MA: Allyn \& Bacon, 1979, pp. 389-438. 
[11] E. Brumberger and C. Lauer, The evolution of technical communication: An analysis of industry job postings, Technical Communication, vol. 62, no. 4, pp. 224-243, 2015.

[12] S. M. Buckl, Developing organization-specific enterprise architecture management functions using a method base Ph. D. dissertation, Department of Informatics XIX, Technical University Munich, 2011.

[13] S. Carliner, C. Castonguay, E. Sheepy, O. Ribeiro, H. Sabri, C. Saylor, and A. Valle, The job of a performance consultant: A qualitative content analysis of job descriptions, European Journal of Training and Development, vol. 39, no. 6, pp. 458-483, 2015.

[14] C. M. Chang, Service Systems Management and Engineering: Creating Strategic Differentiation and Operational Excellence. Hoboken, NJ: John Wiley and Sons, 2010.

[15] H.-I. Chen and Y. Zhang, Educating data management professionals: A content analysis of job descriptions, The Journal of Academic Librarianship, vol. 43, pp. 18-24, 2017.

[16] J. A. Colquitt and C. P. Zapata-Phelan, Trends in theory building and theory testing: A five-decade study of the academy of management journal, Academy of Management Journal, vol. 50, no. 6, pp. 1281-1303, 2007.

[17] J. W. Creswell, Research Design: Qualitative, Quantitative, and Mixed Methods Approaches, 4th ed. Thousand Oaks, CA: Sage, 2013.

[18] H. Demirkan, R. J. Kauffman, J. A. Vayghan, H.-G. Fill, D. Karagiannis, and P. Maglio, Service-oriented technology and management: Perspectives on research and practice for the coming decade, Electronic Commerce Research and Applications, vol. 7, no. 4, pp. 356-376, 2008.

[19] DODAF. (2010) The DoDAF architecture framework version 2.02. Department of Defence Architecture Officer, United States Department of Defense. [Online]. Available: https://dodcio.defense.gov/Portals/0/Documents /DODAF/DoDAF v2-02 web.pdf.

[20] B. Downe-Wamboldt, Content analysis: Method, applications, and issues, Health Care for Women International, vol. 13, no. 3, pp. 313-321, 1992.

[21] A. C. Edmondson and S. E. McManus, Methodological fit in management research, Academy of Management Review, vol. 32, no. 4, pp. 1155-1179, 2007

[22] S. Elo and H. Kyngäs, The qualitative content analysis process, Journal of Advanced Nursing, vol. 62, no. 1, pp. $107-115,2008$.

[23] Y. Fang, O. Henfridsson and S. L. Jarvenpaa, Editorial on generating businesses and social value from digital entrepreneurship and innovation, Journal of Strategic Information Systems, vol. 27, no. 4, pp. 275-277, 2018.

[24] D. F. Feeny and B. Ives, In search of sustainability: Reaping long-term advantage from investments in information technology, Journal of Management Information Systems, vol. 7, no. 1, pp. 27-46, 1990.

[25] D. F. Feeny and L. P. Willcocks, Core IS capabilities for exploiting information technology, Sloan Management Review, vol. 39, no. 3, pp. 9-21, 1998.

[26] M. J. Gallivan, D. P. Truex III, and L. Kvasny, Changing patterns in IT skill sets 1988-2003: A content analysis of classified advertising, Database for Advances in Information Systems: Summer 2004, vol. 35, no. 3, pp. 64-87, 2004

[27] A. Gardiner, C. Aasheim, P. Rutner, and S. Williams, Skill requirements in big data: A content analysis of job advertisements, Journal of Computer Information Systems, vol. 58, no. 4, pp. 374-384, 2018.

[28] C. Gellweiler. Collaboration of project managers and solution architects, International Journal of Human Capital and Information Technology Professionals, vol. 10, no. 4, 2019, to be published.

[29] C. Gellweiler and L. Krishnamurthi, Editorial: How digital innovators achieve customer value, Journal of Theoretical and Applied Electronic Commerce Research, vol. 15, no. 1, pp. I-VIII, 2020.

[30] D. A. Gioia, K. G. Corley and A. L. Hamilton, Seeking qualitative rigor in inductive research: Notes on the Gioia methodology, Organizational Research Methods, vol. 16, no. 1, pp. 15-31, 2012.

[31] M. Gore, Thoughts on the information system architect role, in Proceedings of ITCC 2003, International Conference on Information Technology: Computers and Communications 1197617. Las Vegas, NV. 2003, pp. 706-710.

[32] J. Gøtze, The changing role of the enterprise architect, in Proceedings of 17th IEEE International Enterprise Distributed Object Computing Conference Workshops. Vancouver, IEEE Computer Society, Canada., 2013, pp. 319-326.

[33] U. H. Graneheim and B. Lundman, Qualitative content analysis in nursing research: Concepts, procedures and measures to achieve trustworthiness, Nurse Education Today, vol. 24, no. 2, pp. 105-112, 2004.

[34] Y. Grushka-Cockayne, V. Holzmann, H. Weisz, and D. Zitter, A new hybrid approach for selecting a project management methodology, presented at the PMI Global Congress EMEA. London, England. Newtown Square, PA: Project Management Institute, 2015.

[35] D. B. Gutierrez and L. T. Martinez. (2000) A focus on a b2b e-commerce architecture. Researchgate. [Online]. Available: https://www.researchgate.net/publication/2408531

[36] I. Hanschke, Enterprise Architecture Management - Einfach und Effektiv. Munich: Carl Hanser, 2012.

[37] N. Hong, J. Yoo and S. Cha, Customization of scrum methodology for outsourced e-commerce projects, in Proceedings of Asia-Pacific Software Engineering Conference. Sydney, Australia. IEEE Computer Society, 2010, pp. 310-315.

[38] O. Henfridsson, L. Mathiassen and F. Svahn, Managing technological change in the digital age: The role of architectural frames, Journal of Information Technology, vol. 29, no. 1, pp. 27-43, 2014.

[39] O. Henfridsson, J. Nandhakumara, H. Scarbrough, and N. Panourgias, Recombination in the open-ended value landscape of digital innovation, Information and Organization, vol. 28, no. 2, pp. 89-100, 2018.

[40] H.-F. Hsieh and S. E. Shannon, Three approaches to qualitative content analysis, Qualitative Health Research, vol. 15, no. 9, pp. 1277-1288, 2005. 
[41] IIBA, A Guide to Business Analysis Body of Knowledge (BABOK V3.0). Toronto, Canada: International Institute for Business Analysis, 2015.

[42] ISACA, COBIT V5 - A Business Framework for the Governance and Management of Enterprise IT. Rolling Meadows, IL: Information Systems Audit and Control Association, 2012.

[43] ISO/IEC/IEEE, Systems and software engineering-Architecture description, International standard 42010:2011(E). Geneva: International Organization for Standardization, 2011.

[44] V. Josyula, M. Orr and G. Page, Cloud Computing: Automating the Virtualized Data Center. Indianapolis, IN: Cisco Press, 2012.

[45] J. Kaidalova, K. Sandkuhl and U. Seigerroth, Challenges in integrating product-IT into enterprise architecture - a case study, Centeris - International Conference on Enterprise Information Systems, Procedia Computer Science, vol. 121, pp. 525-533, 2017.

[46] M. A. Kennan, P. Willard, D. Cecez-Kecmanovic, and C. S. Wilson, IS knowledge and skills sought by employers: A content analysis of Australian IS early career online job advertisements, The Australasian Journal of Information Systems, vol. 15, no. 2, 2008.

[47] P. Khalifa. Architectural framework of e-commerce. Academia. [Online]. Available: https://www.academia.edu/ 8564886/ARCHITECTURAL FRAMEWORK OF E COMMERCE?email work card=view-paper

[48] B. Khasnabish, J. Chu, S. Ma, N. So, P. Unbehagen, M. Morrow, M. Hasan, Y. Demchenko, and Y. Meng. (2015) Cloud reference framework. Internet Engineering Task Force. [Online]. Available: https://tools.ietf.org/html/draftkhasnabish-cloud-reference-framework-08

[49] P. Kögler. (2015) IT architectures in e-commerce: The effects of modularity, integration and type of components on e-service quality. Essay. [Online]. Available: https://essay.utwente.nl/67428/1/Koegler BA BMS.pdf

[50] J. J. Korhonen and M. Halén, Enterprise architecture for digital transformation, in Proceedings of the 2017 Conference on Business Informatics (CBI). Thessaloniki, Greece. IEEE Computer Society, 2017, pp. 349-358.

[51] K. Krippendorf, Content Analysis: An Introduction to its Methodology, 2nd ed. Thousand Oaks, CA: Sage, 2004.

[52] J. Luftman, Assessing IT/business alignment, Information Systems Management, vol. 20, no. 4, pp. 9-15, 2003.

[53] A. Martin, D. Dmitriev and J. Akeroyd, A resurgence of interest in information architecture, International Journal of Information Management, vol. 30, no. 1, pp. 6-12, 2010.

[54] P. Mayring. (2000, June) Qualitative content analysis. Forum: Qualitative Social Research. [Online]. Available: http://www.qualitative-research.net/index.php/fqs/article/view/1089/2385.

[55] G. Mentzas, Implementing an IS strategy-a team approach, Long Range Planning, vol. 10, no. 1, pp. 84-95,1997.

[56] M. Mouratidou, V. Lourdas, A. Chatzigeorgiou, and C. K. Georgiadis, An assessment of design patterns' influence on a java-based e-commerce application, Journal of Theoretical and Applied Electronic Commerce Research, vol. 5, no.1, pp. 25-38, 2010.

[57] A. Nadeem, B. Abedin, N. Cerpa, and E. Chew, Editorial: Digital transformation \& digital business strategy in electronic commerce - The role of organizational capabilities, Journal of Theoretical and Applied Electronic Commerce Research, vol. 13, no. 2, pp. I-VIII, 2018.

[58] J. A. O'Brien and G. M. Marakas, Management Information Systems. 10th ed. New York: McGraw-Hill, 2010.

[59] D. H. Olsen, Enterprise architecture management challenges in the Norwegian health sector, Centeris international conference on enterprise information systems, Procedia Computer Science, vol. 121, pp. 637-645, 2017.

[60] M. P. Papazoglou and W.-J. van den Heuvel, Service-oriented design and development methodology, International Journal of Web Engineering and Technology, vol. 2, no. 4, pp. 412-442, 2006.

[61] J. Park and C. Lu, Metadata professionals: Roles and competencies as reflected in job announcements, 20032006, Cataloging \& Classification Quarterly, vol. 47, no. 2, pp. 145-160, 2009

[62] J. Park, C. Lu and L. Marion, Cataloging professionals in the digital environment: A content analysis of job descriptions, Journal of the American Society for Information Science and Technology, vol. 60, no. 4, pp. 844857, 2009.

[63] F. Pigni, G. Piccoli and R. Watson, Digital data streams: Creating value from the real-time flow of big data, California Management Review, vol. 58, no. 3, pp. 5-25, 2016.

[64] C. Pope, S. Ziebland and N. Mays, Qualitative research in health care: Analysing qualitative data, British Medical Journal, vol. 320, no. 7227, pp. 114-116, 2000

[65] B. D. Prasad, Content analysis - A method in social science research, in Research Methods for Social Work (D. K. Lal Das and V. Bhaskaran, Eds.). New Delhi, India: Rawat, 2008, pp. 173-193.

[66] Project Management Institute, A Guide to the Project Management Body of Knowledge (PMBOK), 6th ed. Newtown Square, PA: Project Management Institute, 2017.

[67] Project Management Institute, Requirements Management: A Practice Guide. Newtown Square, PA: Project Management Institute, 2016

[68] Z. Qin, Introduction to E-commerce. Beijing: Tsinghua University Press and Berlin. Heidelberg: Springer, 2009.

[69] Z. Rajabi, B. Minaei and M. A. Seyyedi, Enterprise architecture development based on enterprise ontology, Journal of Theoretical and Applied Electronic Commerce Research, vol. 8, no. 2, pp. 85-95, 2013.

[70] J. F. Rayport and B. J. Jaworski, E-commerce. Singapore: McGraw-Hill, 2001.

[71] M. Sandelowski, Sample size in qualitative research, Research in Nursing \& Health, vol. 18, no. 2, pp. 179-183, 1995.

[72] M. Saunders, P. Lewis and A. Thornhill, Research Methods for Business Students, 7th ed. Harlow: Pearson, 2016. 
[73] J. Schekkerman. (2011) Enterprise architecture tool selection guide v. 6.3. Institute for Enterprise Architecture Developments. [Online]. Available: https://www.enterprise-architecture.info/documents/Enterprise\%20Architec ture\%20Tool\%20Selection\%20Guide\%20v6.3.pdf.

[74] K. Smolander, Four metaphors of architecture in software organizations: Finding out the meaning of architecture in practice, in Proceedings of the 2002 International Symposium on Empirical Software Engineering (ISESE'02), Nara, Japan. IEEE Computer Society, 2002, pp. 211-221.

[75] M. S. Sodhi and B.-G. Son, Content analysis of OR job advertisements to infer required skills, The Journal of the Operational Research Society, vol. 61, no. 9, pp. 1315-1327, 2010.

[76] F. Steinmann, K.-I. Voigt and T. Schaeffler, Engineering competences: A content analysis of job advertisements, in Proceedings of PICMET '13: Technology Management for Emerging Technologies. San Jose, CA. 2013, pp. 1925-1929.

[77] S. Stemler. (2001) An overview of content analysis. Practical Assessment, Research \& Evaluation. [Online]. Available: http://PAREonline.net/getvn.asp?v=7\&n=17

[78] K. J. Stevens and G. T. Timbrell, The implications of e-commerce for software project risk: A preliminary investigation, in Seeking Success in E-Business - A Multidisciplinary Approach (K. V. Andersen, S. Elliot, P. Swatman, E. Trauth, and N. Bjørn-Andersen, Eds.). New York: Springer Science and Business Media, 2003, pp. 327-344.

[79] C. Strano and Q. Rehmani, The role of the enterprise architect, Information Systems and e-Business, vol. 5, no. 4, pp. 379-396, 2007.

[80] Y. Suseno, C. Laurell and N. Sick, Assessing value creation in digital innovation ecosystems: A social media analytics approach, Journal of Strategic Information Systems, vol. 27, no. 4, pp. 335-349, 2018.

[81] The Open Group, The TOGAF Standard Version 9.2. Zaltbommel: Van Haren Publishing, 2018.

[82] B. Thönssen and M. von Dewitz, A label is not enough - Approach for an enterprise architecture role description framework, centeris - international conference on enterprise information systems, Procedia Computer Science, vol. 138, pp. 409-416, 2018

[83] D. Trabucchi, T. Buganza and E. Pellizzoni, Give away your digital services - leveraging big data to capture value, Research-Technology Management, vol. 60, no. 2, pp. 43-52, 2017.

[84] S. Tumbas, N. Berente and J. vom Brocke, Digital innovation and institutional entrepreneurship: Chief digital officer perspectives of their emerging role, Journal of Information Technology, vol. 33, no.3, pp. 188-202, 2018.

[85] M. Vaismoradi, H. Turunen and T. Bondas, Content analysis and thematic analysis: Implications for conducting a qualitative descriptive study, Nursing and Health Sciences, vol. 15, pp. 398-405, 2013.

[86] A. H. van de Ven, Engaged Scholarship: A Guide for Organizational and Social Research. New York: Oxford University Press, 2007.

[87] R. Wagter, H. A. Proper and D. Witte, Enterprise architecture: A strategic specialism, in Proceedings of 2012 IEEE 14th International Conference on Commerce and Enterprise Computing (CEC). Hangzhou, China. IEEE Computer Society, 2012, pp. 1-8.

[88] S. R. Wilkins, Designing for Cisco Internetwork Solutions. 3rd ed. Indianapolis, IN: Cisco Press, 2012.

[89] E. Woods, Return of the Pragmatic Architect, IEEE Software, May/June 2014. Washington, DC: IEEE Computer Society, 2014.

[90] Y. Yoo, R. J. Boland, K. Lyytinen, and A. Majchrzak, Organizing for innovation in the digitized world, Organization Science, vol. 23, no. 5, pp. 1398-1408, 2012

[91] A. Zachman, A framework for information systems architecture, IBM Systems Journal, vol. 26, no. 3, pp. 276292, 1987.

[92] A. Zimmermann, R. Schmidt, D. Jugel, and M. Möhring, Evolving enterprise architectures for digital transformations, in Digital Enterprise Computing 2015, Lecture Notes in Informatics (LNI) (A. Zimmermann and A. Rossmann, Eds.). Bonn, Germany: Gesellschaft für Informatik, 2015, pp. 183-193. 


\section{Appendix A: Sample A}

\begin{tabular}{|c|c|c|c|}
\hline Set-ID & Job Ad Title & Advertizer & Architect Type \\
\hline A-1 & Lead Software Security Architect & Wirecard AG & Software \\
\hline $\mathrm{A}-2$ & Software Architect Sensor Fusion Automated & Continental AG & Software \\
\hline $\mathrm{A}-3$ & IT Architect Infrastructre \& Network & Altran Deutschland S.A.S. \& Co. KG & Solution (Other) \\
\hline $\mathrm{A}-4$ & Global Program Manager \& Solution Architect & Merck KGaA & Solution \\
\hline $\mathrm{A}-5$ & Infrastructure Architect & RWE & Solution (Other) \\
\hline $\mathrm{A}-6$ & Software Solution Architect - loT & Hilti Entwicklungsgesellschaft mbH & Solution \\
\hline $\mathrm{A}-7$ & IT Architect & Sixt Autovermietung & Software (Other) \\
\hline $\mathrm{A}-8$ & Software Architect for Computer Vision & Zeiss & Software \\
\hline $\mathrm{A}-9$ & (Senior) Software Architect & QIAGEN GmbH & Software \\
\hline$A-10$ & System Architect for SLAM & Bosch Gruppe & Solution (System) \\
\hline $\mathrm{A}-11$ & Solutions Architect & Schrödinger $\mathrm{GmbH}$ & Solution \\
\hline $\mathrm{A}-12$ & System Architect & HARMAN International & Solution (System) \\
\hline $\mathrm{A}-13$ & Solution Architect & Configit $\mathrm{GmbH}$ & Solution \\
\hline $\mathrm{A}-14$ & (Senior) CRM Data Architect & QIAGEN GmbH & Solution (Data) \\
\hline $\mathrm{A}-15$ & Software Architect IT & Red Bull Media House GmbH & Software \\
\hline $\mathrm{A}-16$ & Integration Architect & E.ON Business Services GmbH & Solution (Other) \\
\hline $\mathrm{A}-17$ & Software Architect Computed Tomography & Siemens AG & Software \\
\hline A-18 & Cloud Solution Architect & Henkel AG \& Co. KGaA & Solution \\
\hline A-19 & Lead System Architect DevOps & Kühne + Nagel (AG \& Co.) KG & Solution (System) \\
\hline $\mathrm{A}-20$ & Architect - Science Workflow Web Platform & ZEISS & Software (Other) \\
\hline $\mathrm{A}-21$ & Solutions Architect & Nakisa GmbH & Solution \\
\hline A-23 & Solution Architect Dynamics NAV & thyssenkrupp Access Solutions & Solution \\
\hline $\mathrm{A}-24$ & Digital Operations Architect & thyssenkrupp Elevator AG & Solution (Other) \\
\hline $\mathrm{A}-25$ & Solutions Architect - Customer Experience & KANTAR & Solution \\
\hline A-26 & Senior Architect Linux & DNVGL & Solution (Other) \\
\hline $\mathrm{A}-27$ & Big Data Architect & Altran Deutschland S.A.S. \& Co. KG & Solution (Data) \\
\hline $\mathrm{A}-28$ & Big Data Architect & Cognizant Technology Solutions & Solution (Data) \\
\hline A-29 & Enterprise Architect & Henkel AG \& Co. KGaA & Enterprise \\
\hline $\mathrm{A}-30$ & Digital Delivery Architect & John Deere GmbH \& Co. KG & Software (Other) \\
\hline $\mathrm{A}-31$ & Cyber Security Architect - Infiotainment & MBition $\mathrm{GmbH}$ & Solution (Security) \\
\hline A-32 & Lead IT Architect & thyssenkrupp Elevator AG & Enterprise \\
\hline A-33 & System Architect & Veoneer Germany GmbH & Solution (System) \\
\hline A-34 & Software Cloud Architect & Haufe Group & Software \\
\hline A-35 & Enterprise Integration Architect & $\mathrm{PwC}$ & Software (Other) \\
\hline $\mathrm{A}-37$ & Software Architect $(\mathrm{w} / \mathrm{m})$ Virtual validation in & Volkswagen AG & Software \\
\hline $\mathrm{A}-38$ & Al Algorithm Architect for automated Driving & Bosch Gruppe & Software (Other) \\
\hline $\mathrm{A}-40$ & Software Architect in API Design in Bosch & Bosch Gruppe & Software \\
\hline $\mathrm{A}-41$ & PLM Solution Architect & Atlas Copco Energas $\mathrm{GmbH}$ & Solution \\
\hline $\mathrm{A}-42$ & Data Architect (m/f)- Performance & Ernst \& Young GmbH & Solution (Data) \\
\hline $\mathrm{A}-43$ & System Architect - Infotainment & MBitionGmbH & Solution (System) \\
\hline $\mathrm{A}-44$ & eBusiness and Integration Architect & Trinseo Deutschland GmbH & Solution (Other) \\
\hline $\mathrm{A}-45$ & IAM Solution Architect Flexible & Danfoss & Solution \\
\hline $\mathrm{A}-46$ & Cloud Platform Architect & E.ON Business Services GmbH & Solution (Other) \\
\hline $\mathrm{A}-47$ & Senior Enterprise Architect Transition \& & Deutsche Telekom AG & Enterprise \\
\hline A-48 & IOT Architect & Cognizant Technology Solutions & Solution (Other) \\
\hline $\mathrm{A}-49$ & Cyber Security Architect & Daimler FleetBoard GmbH & Solution (Security) \\
\hline $\mathrm{A}-50$ & ERP Solution Architect - Services & GE Power & Solution \\
\hline $\mathrm{A}-52$ & Enterprise Architect Energy Networks & E.ON Business Services GmbH & Enterprise \\
\hline $\mathrm{A}-53$ & IT-Architect Web Solutions & Allianz Technology SE & Solution \\
\hline $\mathrm{A}-56$ & System Architect - Embedded Systems \& & Elektrobit Automotive GmbH & Solution (System) \\
\hline $\mathrm{A}-57$ & Data Architect & E.ON Business Services GmbH & Solution (Data) \\
\hline $\mathrm{A}-58$ & ABAP Application Developer and Architect & Knorr-Bremse Services GmbH & Solution (Other) \\
\hline $\mathrm{A}-59$ & Enterprise Architect Technology \& Platforms & E.ON Business Services GmbH & Enterprise \\
\hline $\mathrm{A}-60$ & Security Architect & Knorr-Bremse Services $\mathrm{GmbH}$ & Solution (Security) \\
\hline $\mathrm{A}-61$ & Information Security Architect & E.ON Business Services GmbH & Solution (Security) \\
\hline $\mathrm{A}-62$ & Network Architect_HCL Technologies & HCL GREAT BRITAIN LIMITED & Solution (Other) \\
\hline $\mathrm{A}-63$ & Senior Software Architect Connected Things & Robert Bosch GmbH & Software \\
\hline $\mathrm{A}-64$ & IT Functional Architect & Boehringer Ingelheim & Enterprise \\
\hline A-65 & Business Technology Architects & Bucher Hydraulics $\mathrm{GmbH}$ & Enterprise \\
\hline A-66 & IT Enterprise Architect & Siegwerk Druckfarben AG \& Co. & Enterprise \\
\hline A-67 & Senior Mobile Architect & IBM Deutschland GmbH & Solution (Other) \\
\hline A-68 & Architect Online Systems \& eCommerce & Nintendo of Europe $\mathrm{GmbH}$ & Solution (System) \\
\hline A-69 & DWH Developer / Data Architect & Westwing Group AG & Solution (Data) \\
\hline A-70 & Data Architect & Eurowings Digital GmbH & Solution (Data) \\
\hline A-72 & Solution Architect & Sixt Autovermietung & Solution \\
\hline A-74 & Architecture Lead & StepStone $\mathrm{GmbH}$ & Enterprise \\
\hline
\end{tabular}




\section{Appendix B: Sample B}

\begin{tabular}{|c|c|c|c|}
\hline Set-ID & Job Ad Title & Advertizer & Architect Type \\
\hline $\mathrm{B}-1$ & Enterprise Architect & Salt & Enterprise \\
\hline $\mathrm{B}-2$ & Enterprise Architect - Azure & Teck nuovo & Enterprise \\
\hline B-3 & Enterprise Architect - IT Transformation, & La Fosse Associates Ltd & Enterprise \\
\hline B-4 & Enterprise Architect (Application Integration) & Capita Resourcing Ltd (IT & Enterprise \\
\hline B-5 & Lead Enterprise Architect & Jumar Solutions Ltd & Enterprise \\
\hline B-6 & Enterprise Architect (Application Integration) & Capita Sourcing Ltd (IT Resourcing) & Enterprise \\
\hline B-7 & Enterprise Architect & Clinical Professional & Enterprise \\
\hline B-8 & Global Group Enterprise Architect & Marks Sattin & Enterprise \\
\hline B-10 & Enterprise Architect - Birmingham & BCT Resourcing & Enterprise \\
\hline B-11 & Enterprise Architect (Enterprise Architect - & Salt & Enterprise \\
\hline B-12 & Information Enterprise Architect & Shaw Daniels Solutions & Enterprise \\
\hline $\mathrm{B}-13$ & Application Enterprise Architect & Shaw Daniels Solutions & Enterprise \\
\hline B-14 & Enterprise Architect & Capita Sourcing Ltd (IT Resourcing) & Enterprise \\
\hline B-15 & Enterprise Architect - CRM & Verticality Ltd & Enterprise \\
\hline B-16 & Enterprise Architect & Shortliste Recruitment & Enterprise \\
\hline B-17 & Enterprise Architect & Robert Walters Plc & Enterprise \\
\hline B-18 & Digital Enterprise Architect & Shaw Daniels Solutions & Enterprise \\
\hline B-19 & Enterprise Architect Central Birmingham & Oliver James Associates Limited & Enterprise \\
\hline B-20 & Enterprise Architect - Somerset & Redrock Consulting Limited & Enterprise \\
\hline $\mathrm{B}-21$ & Enterprise Architect & Reed Technology Leadership & Enterprise \\
\hline $\mathrm{B}-22$ & Enterprise Architect & CGI Group & Enterprise \\
\hline B-23 & Enterprise Architect & Michael Page Technology & Enterprise \\
\hline B-24 & Enterprise Architect & Shaw Daniels Solutions & Enterprise \\
\hline $\mathrm{B}-25$ & Enterprise Architect & Harvey Nash & Enterprise \\
\hline B-26 & Enterprise Architect & Forsyth Barnes Limited & Enterprise \\
\hline B-27 & Enterprise Architect (Financial Sector) & Jumar Solutions Ltd & Enterprise \\
\hline B-28 & Principal Enterprise Architect & Datasource Computer Employment & Enterprise \\
\hline B-29 & Enterprise Architect & Computer Futures Solutions & Enterprise \\
\hline B-30 & Enterprise Architect & Aviva & Enterprise \\
\hline B-33 & Enterprise Architect & Morson (IT Devision) & Enterprise \\
\hline B-34 & Enterprise Architect (Customer Service) & Dixons Carphone & Enterprise \\
\hline B-35 & Enterprise Architect - Payments & Spring Technology & Enterprise \\
\hline B-36 & Enterprise Architect - Microsoft Transformation & EMBS & Enterprise \\
\hline B-38 & Enterprise Architect & Spring Technology & Enterprise \\
\hline B-39 & Enterprise Architect - Database & Datasource Computer Employment & Enterprise \\
\hline B-40 & Enterprise Architect & Capita Resourcing Ltd (IT & Enterprise \\
\hline $\mathrm{B}-41$ & Enterprise Architect - Telecom/Enterprise & CACI Network Services Ltd & Enterprise \\
\hline $\mathrm{B}-42$ & Tempest Enterprise Architect & Leonardo & Enterprise \\
\hline $\mathrm{B}-43$ & Strategy \& Enterprise Architect & The Dining Club Group & Enterprise \\
\hline B-44 & Enterprise Architect & Network Rail & Enterprise \\
\hline $\mathrm{B}-45$ & Enterprise Architect, Digital Technology & HSBC & Enterprise \\
\hline B-46 & Enterprise Solution Architect & Summit Media Limited & Enterprise \\
\hline B-48 & Enterprise Architect & Aviva & Enterprise \\
\hline B-49 & Enterprise Architect & Oblix It Partners Limited & Enterprise \\
\hline B-50 & Senior Enterprise Architect & Managed Solutions & Enterprise \\
\hline B-51 & Data Architect - Database Enterprise Architect - & Reflex Computer Recruitment & Solution (Data) \\
\hline
\end{tabular}




\section{Appendix C: Sample C}

\begin{tabular}{|c|c|c|c|}
\hline Set-ID & Job Ad Title & Advertizer & Architect Type \\
\hline $\mathrm{C}-1$ & Solution Architect E-Commerce & dress-for-less GmbH & E-Commerce \\
\hline $\mathrm{C}-2$ & Softwarearchitect (m/w) SAP Hybris Commerce & Westfalen AG & E-Commerce \\
\hline $\mathrm{C}-3$ & Solution Architect E-Commerce & ZEISS & E-Commerce \\
\hline C-4 & Ecommerce Solutions Architect & Experis & E-Commerce \\
\hline C-5 & Digital Solutions Architect - Ecommerce Agency & Savvy Media Group & E-Commerce \\
\hline$C-6$ & Application Security Architect - E-Commerce & Ventula & E-Commerce \\
\hline C-7 & API Architect - Leading eCommerce Firm & Ventula & Solution (E-Com.) \\
\hline $\mathrm{C}-8$ & Customer Application Architect - Mcommerce & Project people & E-Commerce \\
\hline
\end{tabular}

